\title{
Business Models, Strategy and Innovation in the New World of Digitization
}

\author{
Petra Domanižová1, František Milichovský1, Karel Kuba ${ }^{2}$ \\ ${ }^{1}$ Brno University of Technology, Faculty of Business and Management, Czech Republic \\ 2Pan-European University, Faculty of Economics and Entrepreneurship, Slovakia
}

\begin{abstract}
The aim of this article is to specify the business models and their use when companies enter to foreign markets. An integral part of this is the digitization of today's world, including business models. The purpose of the article is to map the level of knowledge about business models, the impact of digitization on them and how companies to enter specifically German market from business models point of view. The aim of this article is to compare concept of business model as such, its use and access to digitization. By comparing literary revisions, the author will focus on the Canvas business model, which meets the criteria for entering the foreign markets and its structure and uses it as a "winner" among other models. According to results, it is necessary to prepare internal corporate environment in context to digitization, when trades enter to unknown foreign markets.
\end{abstract}

Keywords: business models, Canvas business model, Lean Canvas business model, foreign markets, innovation, strategy, digitization, Industry 4.0

\section{Introduction}

This article presents the topic of future research with links to the growth of the digital economy in European countries, e-commerce, digital business models, and, above all, the digital transformation of businesses. The digitization trend can ensure competitiveness and sustainability in an international environment. The article also develops the logic of the study, including the goal, survey methodology, research, summary and conclusion. The digital economy is "that part of economic output derived solely or primarily from digital technologies with a business model based on digital goods or services" (Bukht and Heeks, 2017). 
The most valuable businesses in the world have embraced digital business models. According to Financial Times UK, seven out of the ten most valuable companies in the globe in 2010 and 2017 are digital businesses. Digital business model is transforming several businesses around the world examples of which are Alphabet (Google), Facebook, and Amazon. Many authors describe linkage between internet and internationalisation and emphasise the impact of technological development in market entry (Madsen and Servais, 1997; Musteen, Francis and Datta, 2010; Johanson and Martín, 2015; Kim, et al., 2011).

Internationalization is one of the basic concepts that can be encountered when studying export behaviour. It is so closely related to export and its research. According to Katsikeas, Leonidou and Morgan (2000), the export debut is even the most significant point in the process of internationalization of the company. Inter-nationalization is a term that is a superior term to the term export.

As with other export performance terms and concepts, it is not possible to find its only and generally accepted definition and the only theory to explain it in its entirety. This shortcoming is all the more so because the beginnings of internationalization considerations can be found in the works of Adam Smith and David Ricardo (Fillis, 2001) and are more than two centuries old.

Globalization can be seen as a phenomenon where business operations are managed globally and not just in a few selected countries. It is characterized by the worldwide integration of competing markets and businesses facing global competition.

Examples of businesses can be companies that are referred to in the literature as international new ventures or born globals. These have been and are able to internationalize in one single step and do not go through the different phases as these phases are predicted by the internationalization phase models. The existence of born global demonstrates, among other things, that the pace of internationalization of businesses is accelerating.

This research will contribute to new knowledge and understanding of how digital firms evolve and internationalize. This is the first research that deals with the in-depth look at what it represents the business model of the digital internationalization of companies by combining international business knowledge, digital internationalization and business modelling literature.

\section{Theoretical Framework of Internationalization}

A large number of forms of entry to foreign markets can be found in the literature. The traditional criterion according to which the individual methods are classified is their capital intensity. According to this criterion, non-capital and capital input forms are recognized (Kotler and Keller, 2012):

- Indirect export: It is the easiest and most common way to enter foreign markets. Indirect export is suit-able for businesses that do not have enough capital (no or minimal investment required) or sufficient export experience. The disadvantage 
is that the company has no contact with foreign markets and no control over foreign activities. An enterprise can take an active or passive approach to indirect export. An active approach means that the company seeks export opportunities to new markets. In a passive approach, the company exports only occasionally and does not systematically seek out opportunities in foreign markets. The lack of export experience can be overcome through cooperation with an independent intermediary company.

- Direct export: Direct export means that the company no longer needs any intermediaries to secure export activities and bears all the risks associated with activities on foreign markets. It follows that the company no longer has to pay any remuneration to intermediaries. Direct export chooses businesses that already have export experience. The risk is higher than for indirect exports, but the company can influence its operations in foreign markets.

- Contractual forms of entry to foreign markets: In the case of indirect and direct export, the company tries to succeed on foreign markets thanks to its products. Contractual forms of entry to foreign markets represent a fundamentally different way of entering new markets. Businesses enter the international environment with their intangible assets and knowledge that are provided under a contract. There is a relatively low risk associated with this form of entry. The disadvantage is that after the period for which the contract has been concluded, a competitor can use it to grow abroad, using the intangible as-sets and knowledge that were the subject of the contract.

- Joint venture: A joint venture creates a new joint venture that is owned and controlled by two or more businesses. Undertakings having ownership interests in a joint venture retain economic and legal autonomy. The advantage of a joint venture is that it allows a foreign venture to use the knowledge and built-up relationships of a local partner. The disadvantage is the need to find a compromise in strategic decisions, sharing knowledge (similar to licensing) and higher risk.

- Direct investment: Direct foreign investment is the most capital intensive and also the riskiest form of entering foreign markets. An enterprise may purchase an existing company abroad, establish a subsidiary or a foreign branch abroad. The difference between a subsidiary and a foreign branch lies in its legal personality. The subsidiary has legal personality, a foreign branch no: it cannot enter into contractual relations. In the long run, the direct foreign investment of a company can bring a number of benefits. These advantages include lower production costs and the possibility of using investment incentives.

It follows from the above that businesses today can choose from a wide range of entry into foreign markets. Choosing the right form of entry into foreign markets becomes a very difficult decision. The difficulty of the decision is mainly due to its difficult future revision, whether it is time or money.

Schellenberg, Harker and Jafari (2017) research a wide range of literature on ways to enter the international market. This is a crucial and strategic issue for managers in 
growing organizations of all sizes in all sectors. A set of key internationalization theories are then systematically and critically reviewed: transaction cost approach, institutional theory, eclectic paradigm, and inter-nationalization model in Uppsala.

\section{Determination and Definition of Business Model and its Configuration}

This part of article is divided into sections. First, it presents definitions, meanings, and elements of the business model. Second, the configuration and application of business models in international business literature, especially in terms of identifying opportunities and creating value.

Zott and Amit (2008) define a business model as "a structural template that describes the organisation of a focal firm's transactions with all of its external constituents in factor and product markets".

According to Teece (2010, p. 20), a business model is "management's hypothesis about what customers want, how they want it and what they will pay, and how an enterprise can organise to best meet customer needs, get paid well for doing so". This definition is similar to the conceptualisation of a business model by Bossidy, Charan and Burck (2009) who note that a business model consists of: a firm's external realities (financial history of the industry, overall business environment, customer base, root-cause analysis which determine best solutions to the firm's problems); its internal activities (strategy, operations, people and organisation); financial targets (operating margins, cash flow, capital intensity, revenue growth, and return on investment); and importantly iteration which tests and refines the model in different application contexts. See the Figure 1 illustrating the base business model.

Figure 1: The base business model

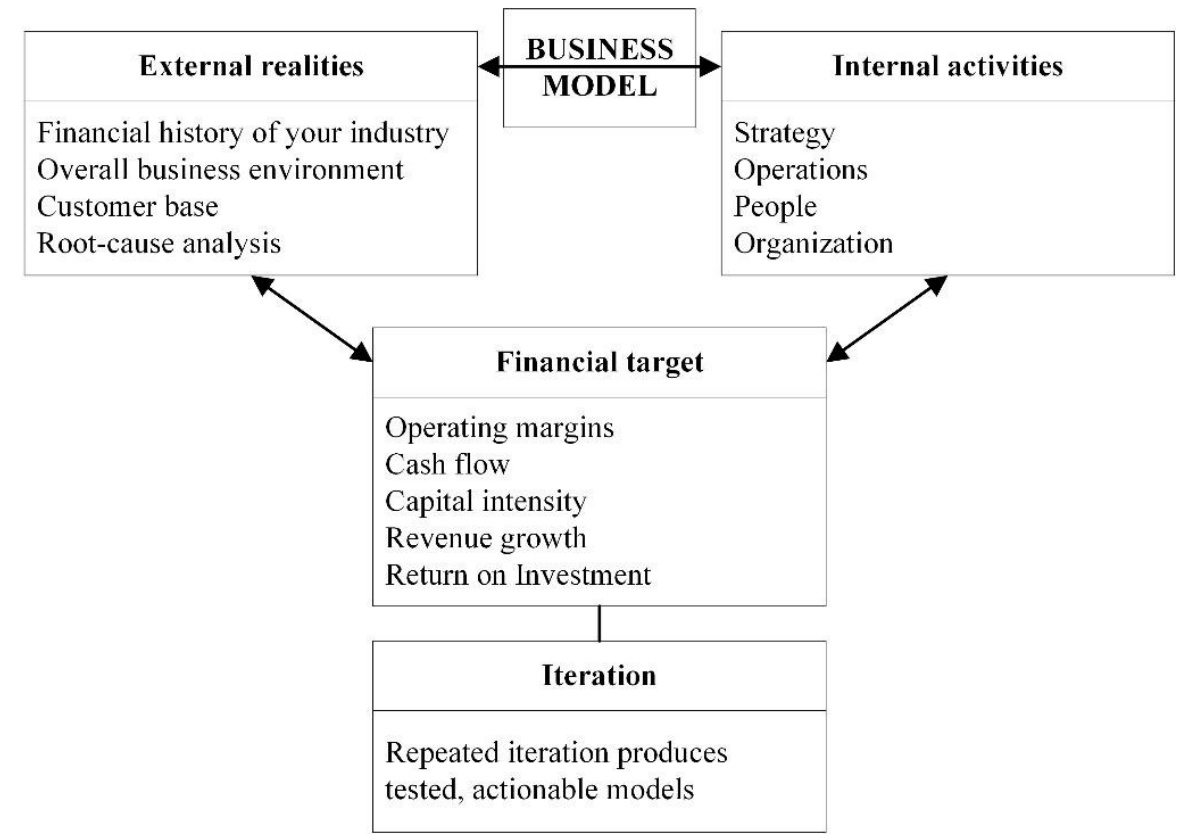

Source: Bossidy, Charan and Burck (2009). 
The following notes discuss further the notion that strategy and business model are intimately linked, though subtly different in meanings.

The above model is referred to as a base business model in this article because it shows the key aspects of a meaningful business model in the way it links the external and internal environments and the usual financial performance metrics.

Business model and strategy are often used interchangeably by many researchers and business practitioners; they are quite distinct but complement each other. Magretta (2002) outlines differences and similarities between strategy and business model. Business model describes how firms create and deliver value to customers, while strategy determines how a firm uses the business model to gain competitive advantage (Markides and Charitou, 2004).

Daas et al. (2012) claim that business model (BM) can be described as "the way a company or company network is trying to make money and create value for customers" (Haaker, Faber and Bouwman, 2006) and can be defined as a plan describing the service definition and intended value for the target group, income sources and provision of service delivery architecture, including a description of the resources needed and an organizational and financial agreement between the involved entrepreneurs, including a description of their roles and the distribution of costs and revenues between business entities.

Shafer, Smith and Linder (2004) mention that many authors offer a definition of business model. "Our own review of relevant literature revealed 12 definitions in publications in 1998-2002." However, none of these definitions has been fully accepted by the business community. This may be due to many different aspects (E-business, strategy, technology and information systems).

Franceschelli, Santoro and Candelo (2018) state that business model is important because it relates to the way a product or technology is commercialized and creates value (Chesbrough, 2010). In fact, a product or technology alone does not create value without an efficient and valuable business model (Johnson et al., 2008). Likewise, it is possible to define a business model as a logic according to which the company it works and creates value for all stakeholders (Casadesus-Masanell and Ricart, 2011).

More specifically, Lindgardt et al. (2009) suggest that the business model is composed of two main elements, namely a value design and an operating model. The first part contains target segments, product or service offered, and revenue model. The second part consists of a value chain, a cost model and an organization.

Osterwalder (2004) discusses whether to compare business models. He states that the general characterization and classification of business models could be an interesting direction of research in order to match them. Timmers (1998) classifies business models between the degree of innovation and the degree of integration.

Mason and Spring (2010) see BM development as positive, improving and innovative. They point out that by the year 2000, the concept of business models was mostly cited by internet businesses. The concept of business model has often been used to explain how 
emerging types of businesses (e-markets, online service providers) could actually make money. This was vital in an industry that was not known to potential investors. Writers at that time saw business models as descriptions of the roles of various "network actors" (Timmers, 1998) and flows between product, service, information and income actors (Weill and Vitale, 2001).

Souto (2015, p. 145) defines business model innovation as "a new configuration of what is done in the company and how it is done, to provide a new value proposition to customers". In other words, it is the new or significantly improved system of activities required for the generation of a new value propositions.

Burmeister, Lüttgens and Piller (2016) focus on innovation of business models for Industry 4.0, i.e. the implementation of cyber-physical systems across the value chain and the far-reaching digitization of products and processes is considered a significant change in our current industrial system. According to Teece (2010), they define the business model as a managerial hypothesis about what customers want, how they want it. How a business can organize itself to best meet its needs and get paid and make a profit.

\section{Methodology}

The purpose of the research as base for this paper is to find out literary overview, then comparison of author's views on the use of business models, their innovation an adaptation under the influence of digitization. Looking at the creation of own business models, exploring areas of knowledge and possible ways of entering to foreign markets. The aim of this article summary is to compare author's views in the concept of business model as such, its use and access to digitization. Focusing on this area can lead to future research. This literature review focuses on recent literature.

Since it is necessary to determine the relevance of potential business model, it is necessary to examine specification of relevant business models what can be obtained. In order, to achieve this aim it was necessary to choose an approach to achieve the following objectives:

1. Overview of relevant literature focusing on business models;

2. Draw conclusions based on the survey.

To achieve objectives mentioned above, it was necessary to carry out the analysis of selected articles, studies and other publications, which are included in scientific databases.

\section{Results}

The different definitions of business model (see Tab. 1) and terms used to describe the business model process make it difficult for researchers to reach consensus on what 
constitutes a business model (Linder and Cantrell, 2000; Osterwalder, Pigneur and Tucci, 2005; Zott, Amit and Massa, 2011).

Tab. 1: Definitions of business model

\begin{tabular}{|c|c|}
\hline Author & Definition \\
\hline $\begin{array}{l}\text { Amit and Zott, (2001, p. } \\
511 \text { ) }\end{array}$ & $\begin{array}{l}\text { The business model describes content of business } \\
\text { transactions with high control focus as reaction of the } \\
\text { business opportunities in a market. }\end{array}$ \\
\hline $\begin{array}{l}\text { Chesbrough and } \\
\text { Rosenbloom (2002, p. } \\
529)\end{array}$ & $\begin{array}{l}\text { The business model includes rational activities, which } \\
\text { link technical potentials with required economic } \\
\text { value. }\end{array}$ \\
\hline Magretta $(2002$, p. 4) & $\begin{array}{l}\text { Business models represent a description how } \\
\text { business activities are realised. Relevant business } \\
\text { model can explains specification of customer and } \\
\text { value for consumer, what lead to money earning with } \\
\text { adequate costs. }\end{array}$ \\
\hline $\begin{array}{l}\text { Morris, Schindehutte } \\
\text { and Allen }(2005, \text { p. } 727)\end{array}$ & $\begin{array}{l}\text { A business model is brief explanation of connections } \\
\text { between individual areas of economics, venture } \\
\text { strategy and construction. These areas are considered } \\
\text { as key ones how is possible to create long-time } \\
\text { sustainable competitive advantage. }\end{array}$ \\
\hline $\begin{array}{l}\text { Casadesus-Masanell and } \\
\text { Ricart (2011, p. 102) }\end{array}$ & $\begin{array}{l}\text { A business model reflects corporate activities that } \\
\text { were realised under condition of complex strategy. }\end{array}$ \\
\hline Teece $(2010$, p. 179) & $\begin{array}{l}\text { A business model expresses the logic, that the facts } \\
\text { and other data support a value offer for the customer, } \\
\text { and a possible structure of revenues and costs for the } \\
\text { firm delivering that value. }\end{array}$ \\
\hline $\begin{array}{l}\text { Zott and Amit (2010, p. } \\
216)\end{array}$ & $\begin{array}{l}\text { It is created on base of interconnection of activities in } \\
\text { the company. These business activities must be } \\
\text { multidisciplinary, crossing boundaries of the } \\
\text { company. }\end{array}$ \\
\hline
\end{tabular}

Source: Authors.

The business model constructs encompassed by these definitions include: the architecture or plan of a business; content, structure and governance of transactions; value creation via exploitation of business opportunities (which directly links business models to entrepreneurship theories); economic value; 'stories' about how enter-prises work; concise representation (typically graphically or in tables) of the interconnections among key aspects of how a business works (as we will see in the business model canvas later, for example); and crucial elements like customer value propositions, revenue and profit formula and processes.

The primary idea is to be able to simply imagine the individual parts of the model as well as the model as a whole. This can be achieved by printing a large copy of the nine Canvas building blocks on a large paper or canvas (hence the name) and placing the copy on the 
wall so that more people can also look at the same model and think, discuss and imagine how to create the right business model (Daniel, Wilson and Myers, 2002).

Components of e-business models by Zott, Amit and Massa (2011) and business model canvas by Osterwalder and Pigneur (2010) are important elements of the conceptual framework for this research. E-business models describe how businesses create value through the internet, for example customer relationshi management, product innovation, and infrastructure. Business model canvas is a strategic management and lean-start-up template for developing a new or documenting existing business models (Osterwalder and Pigneur, 2010). However, it is not only start-ups that benefit from using the business model canvas; it is a strategic tool which facilitates the evolution of existing firms like SMEs and multinational firms. Augmenting the elements of the canvas with e-business components makes it more suitable for supporting the development of digital internationalising firms. This view is implemented in the proposed conceptual framework for this research, later in this chapter. It also helps existing firms to align their new business.

Testing the assumptions of a business model through the steps of the business model canvas and doing appropriate risk quantifications to understand what might occur in the future mong stakeholders in the canvas, helps to achieve good fit between value propositions and customers' needs. Developing prototype products and services using the canvas and testing them with prospective customers is an effective way to build successful business models (Blank and Dorf, 2012; Trimi and Berbegal-Mirabent, 2012).

The researcher notes in a nutshell that the nine stages of an integrated business model are almost equally power-fully developed in both Osterwalder and Pigneur (2010) business model canvas and Amit and Zott (2001) components of e-business models. The components serve as some important elements of conceptual frameworks for building the IBMT in this research. A theoretical justification for using the canvas is the fact that its elements, in addition to explicating the nine important stages of a business model, consider the design features (context, structure, and governance), as well as the design themes (novelty, lock-in, complementarity, and efficiency) noted by Zott and Amit (2010) as core facets of an e-business model. Table 1 depict business model canvas and component of e-business model.

\section{Discussion}

According to the literature used, the author summarizes the fact that not only modern technology of today's age is undergoing dynamic development, but also organizations with their business models have to adapt to rapidly changing trends. In fact, the business model is a personal story that describes how a business works, what value it creates, who it serves, and the way it generates profit. The main goal of each company should be to create a business model to ensure a relatively sustainable or long-term growth and financial sustainability of the business. 
The Canvas business model, as the answer to previous results, ranks among the widely used, clear-cut and clear business models. The authors also emphasize the economic and social benefits of the business model (Kühn et al., 2018; Urban et al., 2018).

Ideally, exploring business models should be done as a whole, but it is also possible to explore selected parts of the model. The author appeals to the importance of adapting the business model to customer needs. Because the fact that a business model works anywhere in the world does not mean it will work in the Europe. Tab. 2 provides a specification of parameters in business model Canvas.

Tab. 2: Specification of parameters in business model Canvas

\begin{tabular}{|c|c|c|c|c|}
\hline $\begin{array}{l}\quad \begin{array}{l}\text { Key partners } \\
\quad \text { (KP) }\end{array} \\
\text { Who are our Key } \\
\text { partners? } \\
\text { Who are our Key } \\
\text { suppliers? } \\
\text { Which Key } \\
\text { resources are we } \\
\text { acquiring from } \\
\text { partners? } \\
\text { Which Key } \\
\text { activities do } \\
\text { partners perform? }\end{array}$ & \begin{tabular}{l}
\multicolumn{1}{c}{$\begin{array}{c}\text { Key resources } \\
\text { (KR) }\end{array}$} \\
What Key \\
resources do our \\
Value Propositions \\
requires; our \\
distribution \\
channels; \\
customer \\
relationships; \\
revenue streams?
\end{tabular} & $\begin{array}{l}\quad \begin{array}{l}\text { Value propositions } \\
\text { (VP) }\end{array} \\
\text { What value do we } \\
\text { deliver to the } \\
\text { customer? } \\
\text { Which one of our } \\
\text { customer's problems } \\
\text { are we helping to } \\
\text { solve? } \\
\text { What bundles of } \\
\text { products and services } \\
\text { are we offering to each } \\
\text { Customer Segment? } \\
\text { Which customer needs } \\
\text { are we satisfying? }\end{array}$ & $\begin{array}{l}\quad \text { Channels (C) } \\
\text { Through which } \\
\text { channels do our } \\
\text { customer segments } \\
\text { want to be reached? } \\
\text { How are we reaching } \\
\text { them now? } \\
\text { How are our channels } \\
\text { integrated? } \\
\text { Which ones work best? } \\
\text { Which ones are most } \\
\text { cost-efficient? } \\
\text { How are we integrating } \\
\text { them with customer } \\
\text { routines? }\end{array}$ & $\begin{array}{l}\quad \begin{array}{l}\text { Customer } \\
\text { Segments }\end{array} \\
\quad \quad \quad \text { (CSs) } \\
\text { For whom are } \\
\text { we creating } \\
\text { value? } \\
\text { Who are our } \\
\text { most } \\
\text { important } \\
\text { customers? }\end{array}$ \\
\hline \multicolumn{3}{|c|}{$\begin{array}{l}\text { What are the most important cost inherent in our business model? } \\
\text { Which key resources are most expensive? } \\
\text { Which key activities are most expensive? }\end{array}$} & \multicolumn{2}{|c|}{$\begin{array}{l}\text { For what value are our customers really } \\
\text { willing to pay? } \\
\text { For what do they currently pay? } \\
\text { How are they currently pay? } \\
\text { How would they prefer to pay? } \\
\text { How much does each revenue stream } \\
\text { contribute to overall revenues? }\end{array}$} \\
\hline
\end{tabular}

Source: Authors.

According to the requirements from the market and technology development, canvas business model is considered as rigid tool on the way of supporting businesses in global 
environment. Therefore, Canvas model was transformed according to conditions of lean form and Industry 4.0 into Lean Canvas model. Lean canvas model includes more areas except traditional canvas areas. These new areas are (Maurya, 2012):

- Problem: definition process as prevention of wasting key sources such time, money on the way of creation product or solution;

- Solution: after problem definition it is important to design and describe final product;

- Key Metrics: recommendation for start-ups is to define at least one key metric by which is evaluate the range of products or services. Choice of right metric could have significant impact;

- Unfair Advantage: from fundamental of start-up could be defined kind of unfair market advantage because of the uniqueness of provided product.

The basic principles in lean canvas, which help to identify potential risks, help to design plan in better way. These principles are (Nidagundi, Novickis, 2016):

(1) Forming a document with description of future activities (a plan);

(2) Determination of process wastage in connection to designed plan;

(3) Periodic verifications of reached results according to plan.

The core principles of Lean Canvas include six areas, on which organization must focus on (Nidagundi, Novickis, 2016). These areas are as follow:

- Ideas: generating of solution for customer's problems;

- Build: focus on continuous development of corporate activities;

- Product: producing generated solution;

- Measure: description of created results from realised activities;

- Data: data verification according to defined aims;

- Learn: improvement of activities on data base.

All of these areas are put into circle loop, where is necessary to work continuously in long period. The connection of individual areas is shown in Figure 2.

According to Duarte, Rosário and Cruz-Machado (2019) lean business model is important answer on environmental issue of global governance. Companies must adapt and integrate their corporate activities to meet green requirements on the way of improvement of global supply chain. In conditions of industry 4.0 it is important to start apply lean business model in effective definitions of individual parts, and work with the highest influence in digitization processes (Kovacs, 2018). 
Figure 2: The base Lean Canvas Business model life cycle

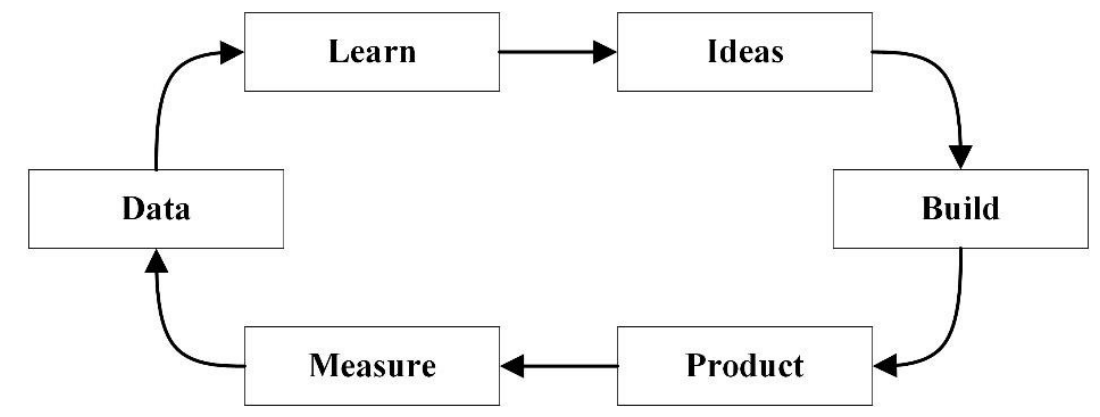

Source: Nidagundi and Novickis (2017).

\section{Conclusion}

The main objective was to assess a greater number of authors in the assessment of business models in the sector under study or across disciplines. Furthermore, the author considers it necessary to try to analyse the possibilities of innovation and adaptation of business models and their impact on the use in the foreign environment. In the future, the Canvas business model (in all potential varies) will certainly be the focus of research and innovation will be the innovation of business models as it enters foreign markets (Doganova and Eyquem-Renault, 2009; Fjeldstad and Snow, 2018).

Lean business model with focus on green requirements is accepted by large professional audience and it is considered as business advantage in competitive battle. Specific position of lean business model is its usage by start-ups regardless to industry or market (Martínez León, Calvo and Amodio, 2017; Ibáñez-Forés et al., 2016; Verrier, Rose and Caillaud, 2016). Relevance of relationship between lean canvas and industry 4.0 verify Sony (2018) and Varela et al. (2019) as actual connection for each company and organization, not only in well-developed countries, but especially in developing countries (Mas-Ruiz, Ruiz-Conde and Calderón-Martinez, 2018; Surdu et al., 2018).

\section{Acknowledgement}

This paper was supported by research project no. FP-J-19-5909, Challenges of digital transformation under conditions of globalization. This project is realised at Faculty of Business and Management, Brno University of Technology.

\section{References}

1. AMIT, R., C. ZOTT, 2001. Value creation in e-business. Strategic Management Journal. 22(6-7), 493-520. Doi: 10.1002/smj.187.

2. BLANK, S.G., B. DORF, 2012. The startup owner's manual. The step-by-step guide for building a great company. $1^{\text {st }}$ ed. $\mathrm{K} \& \mathrm{~S}$ Ranch.

3. BOSSIDY, L., R. CHARAN, Ch. BURCK, 2009. Execution: The discipline of getting things done. Crown Publishing Group. 
4. BUKHT, R., R. HEEKS, 2017. Defining, conceptualising and measuring the Digital Economy. Centre for development informatics global development institute, SEED [online] [accessed: 2019-10-29] Available from http://hummedia.manchester.ac.uk/institutes/gdi/publications/workingpapers /di/di_wp68.pdf

5. BURMEISTER, CH., D. LÜTTGENS, F. T. PILLER, 2016. Business model innovation for Industrie 4.0: why the "industrial internet" mandates a new perspective on innovation. Die Unternehmung. 70, 124-152. Doi: 10.5771/0042-059X-2016-2124.

6. CASADESUS-MASANELL, R., J. E. RICART, 2011. How to design a winning business model. Harvard Business Review. 89(1-2), 100-107.

7. CHESBROUGH, H., 2010. Business model innovation: Opportunities and barriers. Long Range Planning. 43(2-3), 354-363. Doi: 10.1016/j.lrp.2009.07.010.

8. CHESBROUGH, H., R. S. ROSENBLOOM, 2002. The role of the business model in capturing value from innovation: evidence from Xerox Corporation's technology spin-off companies. Industrial and Corporate Change. 11(3), 529-555. Doi: 10.1093/icc/11.3.529.

9. DAAS, D. et al., 2012, Developing a decision support system for business model design. Electronic Markets. 23(3), 251-265. Doi 10.1007/s12525-012-0115-1.

10. DANIEL, E., H. WILSON, A. MYERS, 2002. Adoption of e-commerce by SMEs in the UK. International Small Business Journal. 20(3), 253-270.

11. DOGANOVA, L., M. EYQUEM-RENAULT, 2009. What do business models do? Innovation devices in technology entrepreneurship. Research Policy. 38(10), 15591570. Doi 10.1016/j.respol.2009.08.002.

12. DUARTE, S., C. M. ROSÁRIO, V. CRUZ-MACHADO, 2019. Business Model, Lean and Green Management and Industry 4.0: A Conceptual Relationship. In: Proceedings of the Thirteenth International Conference on Management Science and Engineering Management. 359-372. Doi 10.1007/978-3-030-21248-3_27.

13. FILLIS, I., 2001. Small firm internationalisation: an investigative survey and future research directions. Management Decision. 39(9), 767-783.

14. FJELDSTAD, O. D., CH. C. SNOW, 2018. Business models and organization design. Long Range Planning. 51(1), 32-39. Doi 10.1016/j.lrp.2017.07.008.

15. FRANCESCHELLI, M. V., G. SANTORO, E. CANDELO, 2018. Business model innovation for sustainability: a food start-up case study. British Food Journal. 120(10), 2483-2494. Doi 10.1108/BFJ-01-2018-0049.

16. HAAKER, T., E. FABER, H. BOUWMAN, 2006. Balancing customer and network value in business models for mobile services. International Journal of Mobile Communications. 4(6), 645-661. Doi: 10.1504/IJMC.2006.010360.

17. IBÁÑEZ-FORÉS, V. et al., 2016. Environmental product declarations: exploring their evolution and the factors affecting their demand in Europe. Journal of Cleaner Production. 116, 157-169. Doi 10.1016/j.jclepro.2015.12.078. 
18. JOHANSON, M., O. M. MARTÍN, 2015. The incremental expansion of born internationals: A comparison of new and old born internationals. International Business Review. 24(3), 476-496. Doi 10.1016/j.ibusrev.2014.10.006.

19. JOHNSON, G., K. SCHOLES WHITTINGTON, 2008. Exploring Corporate Strategy: Text \& Cases. Prentice Hall.

20. KATSIKEAS, C. S., L. C. LEONIDOU, N. A. ORGAN, 2000. Firm-Level Export Performance Assessment: Review, Evaluation, and Development. Journal of the Academy of Marketing Science. 28(4), 493-511. Doi: 10.1177/0092070300284003.

21. KIM, D. et al., 2011. The innovativeness of born-globals and customer orientation: Learning from Indian born-globals. Journal of Business Research. 64(8), 879-886. Doi 10.1016/j.jbusres.2010.09.008.

22. KOTLER, P., K. L. KELLER, 2012. Marketing management. $14^{\text {th }}$ ed. New Jersey: Pearson Education.

23. KOVACS, O., 2018. The dark corners of industry 4.0 - Grounding economic governance 2.0. Technology in Society. 55, 140-145. Doi 10.1016/j.techsoc.2018.07.009.

24. KÜHN, A. et al., 2018. Analytics Canvas - A Framework for the design and specification of data analytics projects. Procedia CIRP. 70, 162-167. Doi 10.1016/j.procir.2018.02.031.

25. LINDER, J., S. CANTRELL, 2000. Changing business models: Surveying the landscape, institute for strategic change, Accenture.

26. LINDGARDT, Z. et al., 2009. Business model innovation: When the game gets tough, change the game. Boston Consulting Group [online]. [accesed: 2019-10-29] Available from https://www.bcg.com/documents/file36456.pdf

27. MADSEN, T., P. SERVAIS, 1997. The internationalisation of born globals: An evolutionary process. International Business Review. 6(6), 561-583. Doi 10.1016/S0969-5931(97)00032-2.

28. MAGRETTA, J., 2002. Why business models matter. Harvard Business Review. 80(5), 86-92.

29. MARKIDES, C., C. D. CHARITOU, 2004. Competing with dual business models: A contingency approach. The Academy of Management Executive. 18(3), 22-36.

30. MARTÍNEZ LEÓN, H. C., J. CALVO-AMODIO, 2017. Towards lean for sustainability: Understanding the interrelationships between lean and sustainability from a systems thinking perspective. Journal of Cleaner Production. 142(4), 4384-4402. Doi 10.1016/j.jclepro.2016.11.132.

31. MAS-RUIZ, F. J., E. RUIZ-CONDE, A. CALDERÓN-MARTINEZ, 2018, Strategic group influence on entry mode choices in foreign markets. International Business Review. 27(6), 1259-1269. Doi 10.1016/j.ibusrev.2018.05.007.

32. MASON, K., M. SPRING, 2011. The sites and practices of business models. Industrial Marketing Management. 40, 1032-1041. Doi 10.1016/j.indmarman.2011.06.032.

33. MAURYA, A., 2012. Running lean: iterate from plan A to a plan that works. $2^{\text {nd }}$ ed. Sebastopol (CA): O’Reilly. 
34. MORRIS, M., M. SCHINDEHUTTE, J. ALLEN, 2005. The entrepreneur's business model: Toward a unified perspective. Journal of Business Research. 58(6), 726-735. Doi: 10.1016/j.jbusres.2003.11.001.

35. MUSTEEN, M., J. FRANCIS, D. K. DATTA, 2010. The influence of international networks on internationalization speed and performance: A study of Czech SMEs. Journal of World Business. 45(3), 197-205. Doi 10.1016/j.jwb.2009.12.003.

36. NIDAGUNDI, P., L. NOVICKIS, 2017. Introducing lean Canvas model adaptation in the scrum software testing. Procedia Computer Science. 104, 97-103. Doi 10.1016/j.procs.2017.01.078.

37. OSTERWALDER, A., 2004. The business model ontology a proposition in a design science approach. These, Présentée à l'Ecole des Hautes Etudes Commerciales de l'Université de Lausanne, $169 \mathrm{p}$.

38. OSTERWALDER, A., Y. PIGNEUR, 2010. Business model generation: A handbook for visionaries, game changers, and challengers. Hoboken, New Jersey John Wiley and Sons.

39. OSTERWALDER, A., Y. PIGNEUR, C. L. TUCCI, 2005. Clarifying business models: Origins, present, and future of the concept. Communications of the Association for Information Systems. 16(1), 1-25. Doi 10.17705/1CAIS.01601.

40. SCHELLENBERG, M., M. HARKER, A. JAFARI, 2017. International market entry mode: a systematic literature review. Journal of Strategic Marketing. 26(7), 601627. Doi: 10.1080/0965254X.2017.1339114.

41. SHAFER, S., M., H. J. SMITH, J. C. LINDER, 2004. The power of business models, Business Horizons. 48, 199-207. Doi 10.1016/j.bushor.2004.10.014.

42. SONY, M., 2018. Industry 4.0 and lean management: a proposed integration model and research propositions. Production \& Manufacturing Research. 6(1), 416-432. Doi 10.1080/21693277.2018.1540949.

43. SOUTO, J. E., 2015. Business model innovation and business concept innovation as the context of incremental innovation and radical innovation. Tourism Management. 51, 142-155. Doi: 10.1016/j.tourman.2015.05.017.

44. SURDU, I. et al., 2018. Why wait? Organizational learning, institutional quality and the speed of foreign market re-entry after initial entry and exit. Journal of World Business. 53(6), 911-929. Doi 10.1016/j.jwb.2018.07.008.

45. TEECE, D. J., 2010. Business models, business strategy and innovation. Long Range Planning. 43(2/3), 172-194. Doi 10.1016/j.lrp.2009.07.003.

46. TIMMERS, P., 1998. Business models for electronic markets. Electronic Markets. 8(2), 3-8.

47. TRIMI, S., J. BERBEGAL-MIRABENT, 2012. Business model innovation in entrepreneurship. International Entrepreneurship and Management Journal. 8(4), 449-465. Doi: 10.1007/s11365-012-0234-3.

48. URBAN, M. et al., 2018. Airline categorisation by applying the business model canvas and clustering algorithms. Journal of Air Transport Management. 71(C), 175-192. Doi 10.1016/j.jairtraman.2018.04.005. 
49. VARELA, L. et al., 2019. Evaluation of the Relation between Lean Manufacturing, Industry 4.0, and Sustainability. Sustainability. 11(5), 1-19. Doi $10.3390 /$ su11051439.

50. VERRIER, B., B. ROSE, E. CAILLAUD, 2016. Lean and Green strategy: The Lean and Green House and maturity deployment model. Journal of Cleaner Production. 116, 150-156. Doi 10.1016/j.jclepro.2015.12.022

51. WEILL, P., M. R. VITALE, 2001. Place to space: Migrating to e-business models. Harvard Business School Press, Boston.

52. ZOTT, C., R. AMIT and L. MASSA, 2011. The business model: recent developments and future research. Journal of Management. 37(4), 1019-1042. Doi: $10.1177 / 0149206311406265$

53. ZOTT, C., R. AMIT, 2010. Business model design: An activity system perspective. Long Range Planning. 43(2-3), 216-226. Doi: 10.1016/j.lrp.2009.07.004.

54.ZOTT, C., R. AMIT, 2008. The fit between product market strategy and business model: Implications for firm performance. Strategic Management Journal. 29(1), 126. Doi 10.1002/smj.642.

\section{Contact address of the authors:}

Ing. Petra Domanižová, Department of Management, Faculty of Business and Management, Brno University of Technology, Kolejní 2906/4, 61200 Brno, Czech Republic, e-mail: domanizova@vutbr.cz

Ing. František Milichovský, Ph.D., MBA, DiS., Department of Management, Faculty of Business and Management, Brno University of Technology, Kolejní 2906/4, 61200 Brno, Czech Republic, e-mail: milichovsky@fbm.vutbr.cz

Ing. Karel Kuba, DiS., Faculty of Economics and Entrepreneurship, Pan-European University, Tematínska 10, 85105 Bratislava, Slovakia, e-mail: karel.kuba@peuni.cz 